\title{
Nasal Cancer Mortality in Areas with a High Proportion of Wood and Furniture Workers in Japan
}

\author{
Takesumi Yoshimura ${ }^{1,3}$, Suminori KONO ${ }^{1,4}$, Masanori KURATSUnE ${ }^{1}$ and Shotaro TANI ${ }^{2,5}$ \\ 'Department of Public Health, Faculty of Medicine, Kyushu University. Fukuoka 812, Japan \\ ${ }^{2}$ Mizuma Health Center. Ohkawa 831, Japan
}

\begin{abstract}
To see whether or not death from nasal cancer (ICD 160) increased in the areas where a proportion of woodworkers is high in Japan, two studies were carried out by examining standardized mortality ratios (SMRs) of nasal cancer at a Health Center and in 10 cities selected as wood industry areas. No excess risk of nasal cancer with statistical significance was seen. It would be very difficult to conclude that there is a definite excess risk of nasal cancer among woodworkers in Japan. Further investigation is needed.
\end{abstract}

Key words: nasal cancer, mortality, SMR, woodworker.

(Received 15 August 1983)

\section{Introduction}

In 1965, Macbeth suggested that, based on his observation of case series in Buckinghamshire, England, there was an association between adenocarcinoma of the nasal cavity and paranasal sinus and work in the furniture industry (Macbeth, 1965). This association was confirmed by subsequent epidemiological studies carried out in England (Acheson et al., 1967, 1968; Rang \& Acheson, 1981). This association was also described in many other countries, such as Denmark (Mosbech \& Acheson, 1971), France (Gignoux \& Bernard, 1969), Belgium (Debois, 1969), Australia (Ironside \& Matthews, 1975), Sweden (Engzell, 1979), Holland (Delemarre \& Themans, 1971), USA (Brinton et al., 1977; Roush et al., 1980), Italy (Cecchi et al., 1980) and Canada (Elwood, 1981). It was also reported that the risk of nasal cancer is increased in cabinetmakers and woodmachinists, but not in carpenters and joiners, suggesting that inhalation of wood dust by workers is related to the development of these tumors (Acheson et al., 1981).

In Japan, it would be still difficult to conclude that a cancer risk in the nasal cavity and paranasal sinus has increased among woodworkers, even though two reports have shown an excess risk among woodworkers based on a few cases observed (Shimizu et al., 1979; Hirayama, 1981). In the present study, the authors intended to see whether

${ }^{3}$ Present address : Department of Human Ecology, School of Medicine, University of Occupational and Environmental Health, Japan. Kitakyushu 807, Japan

${ }^{4}$ Present address : Department of Second Internal Medicine, School of Medicine, Fukuoka University. Fukuoka 815, Japan

${ }^{5}$ Present address : Yamato Health Center. Sedaka-machi 835, Japan 
cancer risk has increased in areas where a proportion of woodworkers is fairly high.

\section{Materials and Methods}

Mortality study in the $M$ Health Center

In Fukuoka Prefecture, there is a small city (O City, population : about 50,000) which is one of the largest furniture industry centers in Japan. Among residents aged 15 or over in O Gity, 26 percent were classified as "wood, bamboo, grass, and vine products workers" according to the Occupational Classification used in the 1970 population census.

The jurisdictional district of the M Health Center covers 3 towns and O City, comprising a population of about 90,000. All of the bills of mortality stored at M Health Center from 1971 through 1977 were reviewed and analyzed. Standardized mortality ratios (SMRs) by site and sex were calculated, using the sex and age specific death rates of Fukuoka Prefecture, 1973-76 as a set of standard rates based on vital statistics. The statistical test was made, referring to Bailar's Table (Bailar, 1964). Medical charts for deceased cases in the area were thoroughly reviewed to study their histological diagnosis and occupation.

Mortality analysis in the areas with a high proportion of employees engaged in wood industry

Referring to the census report by prefecture in Japan, 1970, each city and town was examined to see whether the proportion of employees in industried of a) lumber and wood products (except furniture) and b) furniture and mixtures, was more than $10 \%$ of all employees aged 15 years or over in the cities and towns. Ten cities which met the criteria stated above were selected to be analysed to ascertain whether cancer death by site in the city was higher than the cancer death rate in the prefecture in which the city is located. The data tape based on vital statistics in Japan was provided by the Ministry of Health and Welfare with special permission for the present study. Standardized mortality ratios with significance level were calculated, as in the first part of the study.

\section{Results}

\section{Mortality study in the $M$ Health Center}

Six hundred and sixteen and 481 cancer deaths of males and females respectively were observed in the M Health Center, Fukuoka Prefecture during 7 years from 1971 through 1977. The SMR of cancer deaths at all sites for males and females was 1.16 and 1.15 respectively, indicating that all cancer deaths in the area increased with statistical significance at the $1 \%$ level, as shown in Table 1.

Among all cancer sites, stomach for males and females, liver for females and the biliary passages for males were significantly higher than those in cancer deaths in Fukuoka Prefecture. On the other hand, oesophageal cancer mortality was lower in the area. 
Three male deaths and 4 female deaths from nasal cancer were reported in the area during our study period. The SMR for males and females was 0.83 and 1.43, respectively. These figures indicated no consistent increase of nasal cancer deaths in this area.

Histologic type and occupation for seven cases deceased from nasal cancer are shown in Table 2. According to their medical charts, one of them (Case No.6) can not be regarded as a case of nasal cancer, because he was diagnosed as a case of cancer of the palatine tonsil with histology of transitional cell carcinoma.

Among the cases histologically confirmed, none of the cases had a histologic type of

Table 1. Cancer deaths at the M Health Center area (1971-1977)

\begin{tabular}{|c|c|c|c|c|c|c|c|}
\hline \multirow[b]{2}{*}{ Site } & \multirow{2}{*}{$\begin{array}{l}\text { ICD No. } \\
\text { (8th.Rev.) }\end{array}$} & \multicolumn{3}{|c|}{ Male } & \multicolumn{3}{|c|}{ Female } \\
\hline & & Obs.No. & Exp.No." & SMR & Obs.No. & Exp.No. ${ }^{1}$ & SMR \\
\hline All malignant neoplasms & $140-209$ & 616 & 532.6 & $1.16^{* *}$ & 481 & 418.1 & $1.15^{* *}$ \\
\hline Buccal cavity and pharynx & $140-149$ & 3 & 6.0 & 0.50 & 1 & 2.7 & 0.37 \\
\hline Oesophagus & 150 & 20 & 24.9 & 0.80 & 1 & 6.6 & $0.15^{*}$ \\
\hline Stomach & 151 & 271 & 197.0 & $1.38^{* *}$ & 172 & 132.3 & $1.30^{* *}$ \\
\hline Small intestine & 152 & 0 & 1.0 & 0.00 & 1 & 0.8 & 1.25 \\
\hline Large intestine & 153 & 25 & 17.9 & 1.40 & 24 & 20.6 & 1.17 \\
\hline Rectum & 154 & 32 & 21.7 & 1.47 & 15 & 17.9 & 0.84 \\
\hline Liver & $155+197.8$ & 73 & 63.6 & 1.15 & 61 & 33.5 & $1.82^{* *}$ \\
\hline Biliary passages & 156 & 21 & 11.6 & $1.81^{*}$ & 22 & 16.9 & 1.30 \\
\hline Pancreas & 157 & 20 & 23.0 & 0.87 & 15 & 18.5 & 0.81 \\
\hline Nose, nasal cavities and sinuses & 160 & 3 & 3.6 & 0.83 & 4 & 2.8 & 1.43 \\
\hline Larynx & 161 & 6 & 6.1 & 0.98 & 3 & 0.8 & 3.75 \\
\hline Trachea, bronchus and lung & 162 & 73 & 76.7 & 0.95 & 31 & 31.2 & 0.99 \\
\hline Bone & 170 & 4 & 2.6 & 1.54 & 1 & 1.6 & 0.63 \\
\hline Connective tissue & 171 & 1 & 0.8 & 1.25 & 2 & 0.9 & 2.22 \\
\hline Skin & $172-173$ & 2 & 2.3 & 0.87 & 2 & 1.9 & 1.05 \\
\hline Breast & 174 & 0 & 0.2 & 0.00 & 14 & 18.7 & 0.75 \\
\hline Uterus & $180-182$ & - & - & - & 52 & 50.1 & 1.04 \\
\hline Ovary & 183 & - & - & - & 8 & 8.4 & 0.95 \\
\hline Other female genital organ & 184 & - & - & - & 2 & 1.7 & 1.18 \\
\hline Prostate & 185 & 12 & 9.2 & 1.30 & - & - & - \\
\hline Other male genital organ & $186-187$ & 1 & 1.2 & 0.83 & - & - & - \\
\hline Bladder & 188 & 4 & 8.6 & 0.47 & 7 & 5.0 & 1.40 \\
\hline Brain & 191 & 0 & 0.8 & 0.00 & 1 & 0.4 & 2.50 \\
\hline Thyroid gland & 193 & 0 & 1.5 & 0.00 & 4 & 2.9 & 1.38 \\
\hline Lymphosarcoma & 200 & 5 & 4.9 & 1.02 & 3 & 2.8 & 1.07 \\
\hline Hodgkin's disease & 201 & 1 & 1.7 & 0.59 & 2 & 0.9 & 2.22 \\
\hline Lymphatic tissue & 202 & 3 & 6.6 & 0.45 & 4 & 3.6 & 1.11 \\
\hline Multiple myeloma & 203 & 4 & 3.0 & 1.33 & 2 & 3.2 & 0.63 \\
\hline Leukemia & $204-207$ & 10 & 12.5 & 0.80 & 9 & 9.5 & 0.95 \\
\hline Others & & 22 & 23.3 & 0.94 & 18 & 21.5 & 0.84 \\
\hline
\end{tabular}

1) Expected numbers are calculated, based on the site and age specific death rates in Fukuoka Pref. $1973-1976$.

* Significant level of $5 \%$. * Significant level of $1 \%$. 
Table 2. Cases with nasal cancer with histologic type and their occupations

\begin{tabular}{lccccccc}
\hline & Case $^{*}$ & Sex & Year at death & Age at death & Cause of death & Histologic type & Occupation \\
\hline 1. & F.M. & F & 1971 & 56 & Ca. maxillary sinus & Ca. simplex & $\begin{array}{l}\text { Wood painter } \\
\text { (for 10 years) }\end{array}$ \\
2. & S. K. & M & 1971 & 65 & Ca. maxillary sinus & Squamous cell ca. & Farmer \\
3. & T. T. & M & 1971 & 48 & Ca. maxillary sinus & Squamous cell ca. & No record \\
4. & W. S. & F & 1974 & 76 & Malignant tumor of & Not examined & Kimono maker \\
5. & T.M. & F & 1975 & 73 & Ca. maxillary sinus & Not examined & Retail dealers for \\
6. & K. H. & M & 1976 & 77 & Ca. palatine tonsil & Transitional cell ca. Joiner \\
7. & T. K. & F & 1977 & 73 & Ca. maxillary sinus & Squamous cell ca. & Farmer \\
\hline
\end{tabular}

* Cases deceased from nasal cancer (ICD 160) from 1971 through 1977 at the M Health Center.

** Cancer of maxillary sinus was recorded on a death certificate, but on his medical chart cancer of the palatine tonsil was recorded as a clinical diagnosis with histology.

Table 3. Nasal cavity and sinuses (ICD 160) in the 10 selected cities ${ }^{11}$

\begin{tabular}{ccccc}
\hline Sex & Year & Obs. No. & Exp. No. ${ }^{2)}$ & SMR \\
\hline Male & $1969-1972$ & 16 & 13.3 & 1.20 \\
& $1973-1976$ & 11 & 12.9 & 0.85 \\
Female & $1969-1972$ & 13 & 7.9 & 1.65 \\
& $1973-1976$ & 14 & 9.4 & 1.49 \\
\hline
\end{tabular}

1) 10 cities in each of which employees at wood and furniture industries are $10 \%$ or more among total employees were selected, based on the census in 1970.

2) Expected numbers are calculated, based on the site and age specific death rates in each pref. $1969-1972$ and $1973-1976$.

Table 4. Oesophagus (ICD 150) in the 10 selected cities ${ }^{1)}$

\begin{tabular}{ccccc}
\hline Sex & Year & Obs. No. & Exp. No. ${ }^{2 !}$ & \multicolumn{1}{c}{ SMR } \\
\hline Male & $1969-1972$ & 107 & 82.1 & $1.30^{*}$ \\
& $1973-1976$ & 108 & 82.4 & $1.31^{* *}$ \\
Female & $1969-1972$ & 33 & 27.8 & 1.19 \\
& $1973-1976$ & 16 & 27.3 & $0.59^{*}$ \\
\hline
\end{tabular}

1) 10 cities in each of which employees at wood and furniture industries are $10 \%$ or more among total employees were selected, based on the census in 1970.

2) Expected numbers are calculated, based on the site and age specific death rates in each pref. $1969-1972$ and 1973-1976.

* Significant level of $5 \%$.

** Significant level of $1 \%$. 
adenocarcinoma. Regarding occupation, one case (Case No.1) worked as a wood painter for ten years. The occupations of the other cases do not relate to woodworkers.

Mortality analysis in wood industry areas

The number of observed cases and expected cases calculated according to the sets of standard death rates for the ten selected cities were added up respectively to obtain the summary SMRs. The summary SMRs by sex and periods are shown in Table 3 and Table 4.

For nasal cancer in Table 3, the SMR for males in the first period (1969-1972) and in the second period $(1973-1976)$ was 1.20 and 0.85 , respectively. The results for male nasal cancer showed no consistent excess risk. The SMRs for females were 1.65 and 1.49 in the two periods stated above. These slight increases of SMRs were not found to be of statistical significance at the $5 \%$ level.

At each cancer site, excess deaths in 10 cities were examined. None of site specific cancer deaths revealed excess deaths except for oesophageal cancer. As shown in Table 4, the oesophageal cancer death rate of males in 10 cities was significantly high. But in the case of females, deaths from oesophageal cancer in the second period were significantly low.

\section{Discussion}

If the same reasons for the increase of nasal cancer risk as in England and in other countries existed in Japan, it was expected that the risk of nasal cancer among woodworkers in Japan had increased. Therefore, the two approaches in the present study have been carried out to examine the increase of nasal cancer risk in Japan. In the present study, however, no definite excess deaths from nasal cancer in the wood industry areas was obtained.

The results obtained could be explained in two ways. One explanation is that there is no excess risk of nasal cancer among woodworkers in Japan and the other explanation is that even if the risk of nasal cancer among woodworkers has increased, the present study failed to show this increase. For the present purpose of this study, population at risk should be woodworkers. In the present study, however, people who live in the areas where the proportion of wood and furniture workers is high were used as the population at risk for practical reasons. Therefore, apparent risk would be reduced. This might cause the failure to show excessive risk.

It was reported that the latent period for nasal cancer due to occupational exposure in wood and furniture industry was about 43 or 44 years on average (Acheson, 1976; Acheson $e t$ al., 1982). Cases deceased from nasal cancer at the time of the present study might have been reflected by the exposure in wood and furniture industry in 1930s or 1940s. Since it is difficult to obtain the data of exposure status for this period, it is assumed that 
centers for wood and furniture industry in Japan in those days were not very different from the centers of the present study. This might be also one of the factors to show conservative results in the study. However, SMRs for males in the areas did not show any consistent results. This indicates that it would be rather difficult to accept the second explanation.

Therefore from this study, it would be impossible to conclude that there is an excess risk of nasal cancer among woodworkers in Japan. Further investigation to confirm the results should be carried out.

\section{Acknowledgements}

We are indebted to the staff at $\mathrm{M}$ Health Center for data collection, and also to the Ministry of Health and Welfare for their permission to use the death records from vital statistics in Japan.

\section{References}

Acheson, E. D. (1976) : Nasal cancer in the furniture and boot and shoe manufacturing industries. Prev. Med., 5: 295-315.

Acheson, E. D., Cowdell, R. H., Hadfield, E. H. et al. (1968) : Nasal cancer in woodworkers in the furniture industry. Br. Med. J., 2: 587-596.

Acheson, E. D., Cowdell, R. H. \& Rang, E. H. (1981) : Nasal cancer in England and Wales : an occupational survey. Br. J. Ind. Med., 38: 218-224.

Acheson, E. D., Hadfield, E. H. \& Macbeth, R. G. (1967) : Carcinoma of the nasal cavity and accessory sinuses in woodworkers. Lancet, $1: 311-312$.

Acheson, E. D., Winter, P. D. \& Hadfield, E. (1982): Is nasal adenocarcinoma in the Buckinghamshire furniture industry declining? Nature, 299 (5880) : 263-265.

Bailar, J. C. (1964) : Significance factors for the ratio of a Poisson variable to its expectation. Biometrics, 20: $639-643$.

Brinton, L. A., Blot, W. J., Stone, B. J. et al. (1977) : A death certificate analysis of nasal cancer among furniture workers in North Carolina. Cancer Res., 37: 3473-3474.

Cecchi, F., Buiatti, E., Kriebel, D. et al. (1980): Adenocarcinoma of the nose and paranasal sinuses in shoemakers and woodworkers in the province of Florence, Italy (1963-1977). Br. J. Ind. Med., 37 : $222-225$.

Debois, J. M. (1969) : Tumoren van de neusholte bij houtbewerkers. Tijdschr Geneeskd., 25: 92-93.

Delemarre, J. F. M. \& Themans, H. H. (1971) : Het adenocarcinoom van de neusholten. Ned. Tjdschr Geneeskd., 115: 688.

Elwood, J. M. (1981) : Wood exposure and smoking: association with cancer of the nasal cavity and paranasal sinuses in British Columbia. Can. Med. Assoc. J., 124: 1573-1577.

Engzell, U. (1979) : Occupational etiology and nasal cancer. Acta Oto-Laryngol. Suppl., 360: 126-128.

Gignoux, M. \& Bernard, P. (1969): Tumenrs Malignes de l'ethmoide chez les travailleurs du bois. J. Med. Lyon, $50: 731-736$.

Hirayama, T. (1981): Proportion of cancer attributable to occupation obtained from a census, populationbased, large cohort study in Japan. In : Banbury Report 9: Quantification of Occupational Cancer. (Peto, R. \& Schneiderman, M., ed.). Cold Spring Harbor Laboratory, New York, pp. 631-649. 
Ironside, P. \& Matthews, J. (1975) : Adenocarcinoma of the nose and paranasal sinuses in woodworkers in the state of Victoria, Australia. Cancer, 36: 1115-1121.

Macbeth, R. (1965) : Malignant disease of the paranasal sinuses. J. Laryngol. Otol., 79: 592-612.

Mosbeck, J. \& Acheson, E. D. (1971) : Nasal cancer in furniture-makers in Denmark. Dan. Med. Bull., $18(2): 34-35$.

Rang, E. H. \& Acheson, E. D. (1981) : Cancer in furniture workers. Int. J. Epidemiol, 10: $253-261$.

Roush, G. C., Meigs, J.W., Kelly, J. et al. (1980) : Sinonasal cancer and occupation : a case-control study. Am. J. Epidemiol., 111 (2): 183-193.

Shimizu, T., Ohkuni, M. \& Mito, H. (1979) : Malignant tumors in woodworkers in Japan. Acta Medica Kinki Univ., 4 (2) : 421-425.

\section{木工従事者の多い地区での鼻の癌}

吉村 健清1,3 ·古野 純典 ${ }^{1,4} \cdot$ 倉恒 匡徳 ${ }^{1} \cdot$ 渓 正太郎 2,5

九州大学医学部公衆衛生学講坐 2 三㵔保健所

要 旨：我が国の木工作業者の割合の大きい地域において，鼻の癌 (ICD 160)による死亡が高め られているか否かを調べることを目的として，本研究が行われた。木工作業の盛んな地域 として選ばれた，某保健所と10市において，それぞれ鼻の癌の SMR を求める2つの研究 を実施した。その結果，これらの地域において，鼻の癌のリスクの有意な高まりを見出す ことはできず,木工作業者に鼻の癌のリスクが明確に高いとは結論しがたかった。したがっ て, 今後さらに調査をすすめる必要があると考える.

J. UOEH（産業医大誌），5 (4)：433-439 (1983)

3現：産業医科大学公衆衛生学教室

${ }^{4}$ 現：福岡大学医学部第 2 内科学教室

現：山門保健所 